\title{
DETERMINANTS OF LITHUANIAN PATERNAL AND SPOUSAL TIME ALLOCATION WITH CHILDREN
}

\author{
Dmitri M. Medvedovski \\ Bethel University (USA)
}

\begin{abstract}
This article analyzes paternal time allocation with children in Lithuania and explores paternal and spousal cross effects in time investment. Effects of paternal health status, alcohol consumption and health insurance status on paternal-child time allocation are also examined. The research finds a modest after-tax family income effect for paternal time, but not when examining paternal-spousal cross effects for child time investment. Regarding paternal-spousal cross effects, while both are very highly significant statistically, this research finds almost twice the complementarity for the Lithuanian paternal hour with children for spousal time with children than for a spousal hour for paternal time with children. The paper identifies several possible factors in the Lithuanian context contributing to a complementary effect and away from a substitutionary effect. Spousal age and educational effects - the former negative, the latter positive - are found for spousal time allocation with children but not found significant paternally. To our knowledge this is the first study to examine paternal time allocation in Lithuania for children including health status, alcohol consumption, insurance status and paternal/spousal cross effects for time allocation with children. Compared to our previous research, it also supports caution against assuming that parental cross effects on time allocation in a Lithuanian social context mirror such in the U.S.

KEYWORDS: parental-child time allocation, household income modeling, household labor gender effects, labor market.
\end{abstract}

\begin{abstract}
Anotacija
Straipsnyje analizuojamas Lietuvos vyrų vaikams skiriamas laikas ir s vyrų bei abiejų sutuoktinių tam skiriamo laiko skirtumai. Tirta vyrų sveikatos būklès, alkoholio vartojimo ir sveikatos draudimo įtaka laiko, leidžiamo su vaikais, trukmei. Tyrimo rezultatai atskleidè nedidelę šeimos pajamų dydžio koreliaciją su tèčių vaikams skiriamu laiku, tačiau ji nenustatyta tiriant bendrą abiejų tèvų su vaikais praleistą laiką. Nors tiek těčių, tiek abiejų sutuoktinių su vaikais praleidžiamo laiko nauda yra statistiškai reikšminga, tyrimas atskleidè, kad buvimo su tečiu valanda suteikia beveik dvigubai vertingesnè nei abiejų sutuoktinių praleista valanda. Sutuoktinių amžius neigiamai, o įtaka vaikų mokymuisi teigiamai koreliavo su abiejų tėvų vaikams skiriamu laiku, tačiau šie veiksniai nebuvo reikšmingi vien tik vyrų imčiai. Kiek žinoma, tai buvo pirmas Lietuvoje atliktas tyrimas, kai tirta vyrų su vaikais praleidžiamo laiko trukmè, atsižvelgiant ị sveikatos būklès, alkoholio vartojimo ir sveikatos draudimo veiksnius. Lyginant su ankstesniais autoriaus atliktais tyrimais, šis sustiprina abejones, kad tèvu vaikams skiriamo laiko veiksniai yra analogiški JAV.

PAGRINDINIAI ŽODŽIAI: tėvų vaikams skiriamas laikas, namų ūkio pajamų modelis, lyties sąsajos su namų ruošos darbais, darbo rinka.
\end{abstract}




\section{Introduction}

European Community Household Panel (ECHP, 2012) 5-year data ending in 2001 has indicated that the average number of hours that fathers allocate for care of children in Denmark, France, German, Italy, and Spain varies significantly from 7 hours to 19 hours per week while maternal weekly time allocation range for children at the minimum was up 4 times that of the paternal range to double the maximum with much less variation, namely from 30 hours to 38 hours per week. Gender differences in caring for children was greatest in Spain (five times more than paternal) and smallest in Denmark (about one and a half times more).

Activity with children has been found to be a leading investment component where parents strive for better outcomes for them. More working hours by one parent was found to be compensated by more hours with children by the other. Not surprisingly, education and age were highly correlated with wages. Yet, while higher paternal income was also associated with more maternal time devoted towards children, the converse did not hold: increased maternal income does not necessarily translate into fathers spending more time with children (Garcia-Mainar, Molina, \& Montuenga, 2011).

More recent European Community Household Panel data years (2006-2010) includes Lithuania. In 2010 it indicates for children under three, 87\% of families in Lithuania used no formal childcare compared to Denmark where 68\% had 30 or more weekly hours of formal childcare. For children between three and compulsory schooling, Denmark had only $10 \%$ of families with no formal childcare compared to Lithuania's $33 \%$ (down from $43 \%$ in 2005) with the the $27 \mathrm{EU}$ country average being $14 \%$. Lithuania exhibits much less reliance on formalized child care than the EU average and by implication more familial reliance (ECHP, 2012).

Children's responses to surveys may be compared to parental responses. Over 2001-2002 among six countries (Czech Republic, Finland, Greenland, Lithuania, Spain and Ukraine), 13 and 15 year-old students from Ukraine and Spain reported the most time with parents across a variety of activities (TV / video, indoor games, meals, taking walks, going places, visiting friends / family, sports and talking), as one might expect trending lower with age. Children in Finland and Greenland reported spending the least time with parents. Boys notably tended to have more time with parents than girls. 
In a 2007 study, parents spending less time together as the family, specifically among Finns and Lithuanians, had the most negative assessment of children spending time with the parents. Except for watching television, playing video games and meals for boys (2nd highest), Lithuanian families tended toward the mid to lower ranks in activities in the 4-5 hour range across the ages and sexes. Ukrainians spent the most time in talking, television/video, indoor games, meals, and going for walks. Family time investment was also strongly and consistently related to smoking, drinking, and delinquent behavior of children (Zaborskis, Zemmaitiene, Borup, Kuntsche, \& Moreno, 2007). Parental perception of time spent with children (i.e. parental feelings of amount of time allocation with children) has been also studied as a major contributing factor for parental labor supply. (Milkie, Mattingly, Nomaguchi, Bianchi, Robinson, 2004).

Across 14 polities college educated parents tend to spend more time with their children (Norway, USA, UK, Netherlands, Austria, Canada, France, Germany, Italy, Slovenia, Chile, Estonia, South Africa, Palestine, ordered from most to least time with children) (Guryan, Hurst, \& Kearney, 2008). This is striking as more educated parents also spend more time working outside of the home with mothers still spending more time with children than fathers. The contradictory impact of parental education upon parental time allocation with children has been duly explored in academic literature (Craig, 2006). The greatest discrepancies between paternal and maternal time were in Palestine (mothers rank 1st, fathers 12th). The next greatest discrepancy of 6 ranks is for the Netherlands and Austria albeit in opposite directions (father / mother time 4th \& 10th and 8th \& 2nd, respectively). The single Baltic country, Estonia, was 9th of 14. This positive relational coefficient for education and income internationally: may seem surprising given that more educated parents have a higher time opportunity cost. However child time allocation is nonetheless valued more by individuals with higher time opportunity cost. Parents may view time allocation with children as either a market commodity or as a component of the more "enjoyable" activity of household production where time for children is a higher contributor to a parent's utility function. Economic trade off between parental contribution to time spent with children versus various market activities including employment has been explored (Nock, Kingston, 1988). Whether a parent's time allocation is perceived as a market priced commodity or part of affective fulfillment will influence how parents behave. There has been an increasing trend in economic 
literature to measure how people feel based on individual preferences and values (Fleurbaey, 2009).

It should be noted that international parental-child time comparisons present some controversies of measurement and comparability. Findings often do not take into account other important country specific variations such as length of the working day, labor markets, financial support (Kindergeld), and demographic factors (Harvie, Slater, Philp, \& Whetley, 2009). In addition to the impact of market indicators including the wage rate upon the spousal time allocation, the relationship between each spouse's leisure choices were explored. (Connelly, Kimmel, 2009).

Compared to 27 EU member states, Kanopiene (2011) reports for Lithuania comparatively lower male than female employment in 2009 , namely $59.5 \%$ and $60.7 \%$ compared to EU averages of $70.7 \%$ for males and $58.6 \%$ for females. The difference is accounted for in that Lithuanian male unemployment is higher than for females $(17.4 \%$ vs. $10.1 \%)$ and both higher than EU averages $(9.0 \%$ males, $8.8 \%$ females). From 2002 to 2007 female employment in Lithuania increased by 5 percentage points from $57.2 \%$ to $62.2 \%$. With near gender parity for employment it has been said that Lithuania continues the Soviet era tradition (Kanopiene, 2011).

\section{The methodology of the research}

\section{Data}

The survey was reviewed and approved by the institutional review board of the LCC International University, Klaipeda, Lithuania. The data comprised responses of 73 Lithuanian self-identified fathers to a 62-item survey adapted in part from the National Center for Fathering's Personal Fathering Profile instrument of 1990 (National Center for Fathering, 1999). It includes inter alia demographics, household composition by age and sex; education, employment, relationship status and household income and expenditures; spousal characteristics (if applicable); and time allocation with children. Health queries included self-reported health status on a 4-point Likert scale (excellent, good, fair, poor), height, weight, alcohol consumption, physician visits, smoking, and medical insurance. Fifty-three percent of respondents had two children, $21 \%$ one child, $15 \%$ had three children, and only two $(2.7 \%)$ had more than three children. Five (7\%) indicated no children - whether due to child deaths is unclear. Since 1993 the Lithuanian birth rate has been below replacement level (Statistics Lithuania, 
2012, p. 11). For 2011 deaths exceeded births by a stark 19.3\% (Statistics Lithuania, 2012, p. 10). Not surprisingly the Lithuanian government has adopted a prenatal stance while, at the same time, Lithuanians are marrying increasingly late (15min.lt, 2012): First-marriage average age for males jumped from was 27.7 in 2007 to 29.0 in 2011; for Lithuanian women it increased from 25.5 to 26.6 over the same four-year period. Additionally, $11 \%$ of Lithuanian women elected to marry citizens of foreign countries compared to only $5 \%$ of men. In our sample, father ages ranged from 26 to 56, with a higher than anticipated lower bound.

\section{Methods}

Respondents were randomly recruited in 2011 in Klaipeda, Lithuania, and outlying areas. Klaipeda (capital of the like-named county) is located on the Baltic Sea and is the third largest city in Lithuania with a 2011 population of 177,823 . Survey correlations were run across variables. Variables for models had a dependent variable correlation significance of $\mathrm{p}=.10$ or better. I selected Ordinary Least Squares (OLS) regression for modeling parental time allocation for children related to paternal health, consumption of alcohol, and examination of compensatory effects between spouses and other characteristics. OLS regression yields the best linear unbiased parameter estimate when the model is linear in parameters under a random sample (yielding conditional expected means of zero) when independent variables (predictors) lack any exact linear relationship among themselves when measured relatively precisely with independent, normally distributed errors (optimal for $\mathrm{t}$ and $\mathrm{F}$ tests), and (relatively) constant variance in the residuals from the mean (homoscedasticity) ensuring minimum variance in the estimate. For parameter estimates I report both raw betas with standard errors and standardized betas. Standardized betas are obtained by converting raw betas to reflect the change in the dependent variable per 1 standard deviation increase (rather than unit increase) in the predictor (One can perform this conversion by multiplying the raw beta by the ratio of the standard deviations of the dependent and independent variables.) This provides an impact comparison between quite dissimilar variables within a model. In Table 1 results, significance is indicated as $\dagger p \leq .10, * p \leq .05, * * p \leq .01$, and $* * * p \leq .001$. 
Table 1. Time Allocation With Children

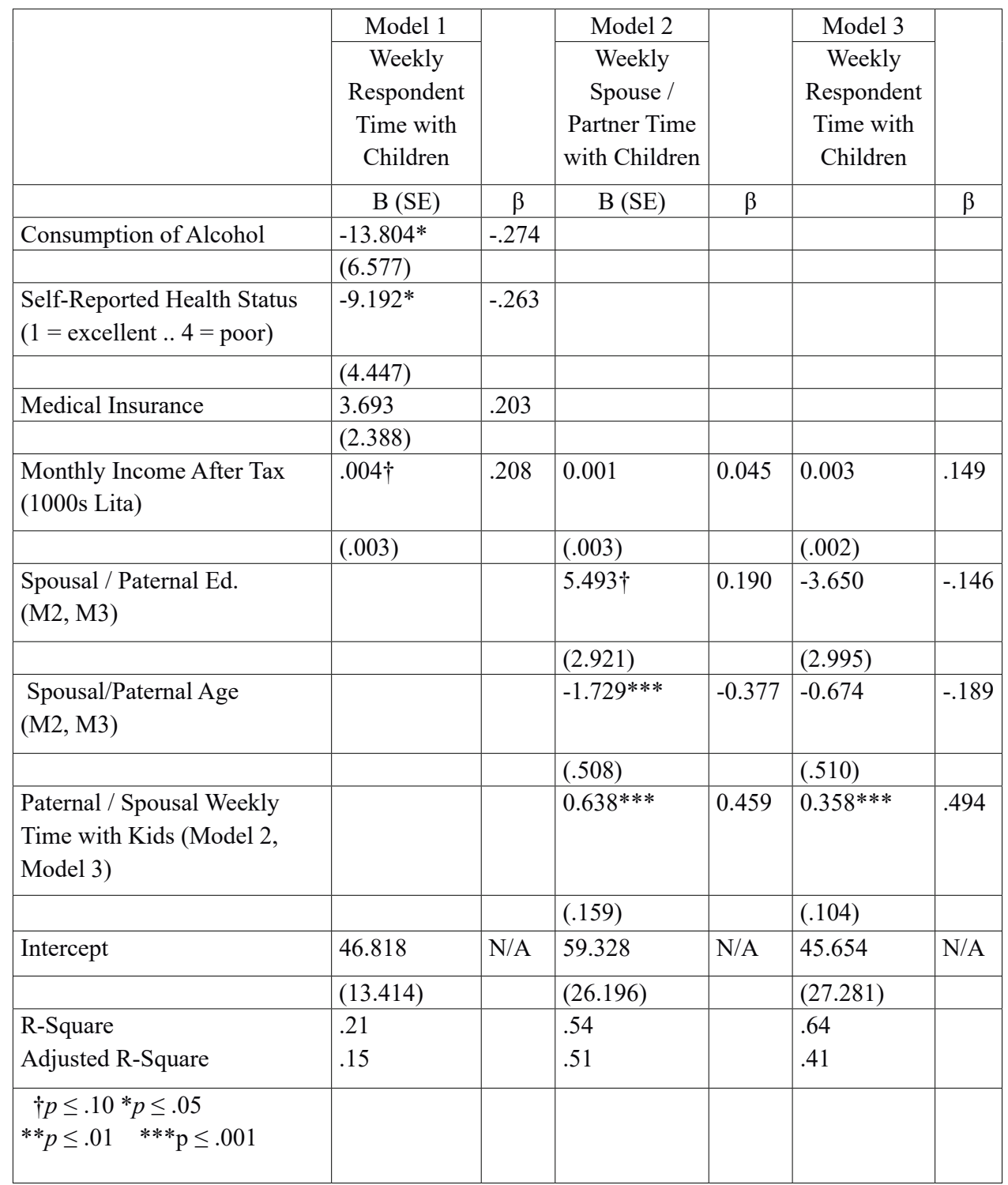


DETERMINANTS OF LITHUANIAN PATERNAL AND SPOUSAL TIME ALLOCATION...

Table 2. Sample Characteristics of the Respondents

\begin{tabular}{|l|l|l|l|l|l|l|l|}
\hline \multicolumn{1}{|c|}{ Characteristic } & \multicolumn{1}{|c|}{$\mathrm{N}$} & Range & $\begin{array}{c}\text { Mini- } \\
\text { mum }\end{array}$ & $\begin{array}{c}\text { Maxi- } \\
\text { mum }\end{array}$ & Mean & SD & Median \\
\hline $\begin{array}{l}\text { Respondent's family } \\
\text { monthly income } \\
\text { (Lithuanian currency) }\end{array}$ & 61.00 & 7280.00 & 220.00 & 7500.00 & 3034.90 & 1299.99 & 2900.00 \\
\hline $\begin{array}{l}\text { Respondent drinking } \\
\text { alcohol }\end{array}$ & 72.00 & 1.00 & 1.00 & 2.00 & 1.28 & 0.45 & 1.00 \\
\hline $\begin{array}{l}\text { Respondent health } \\
\text { condition }\end{array}$ & 72.00 & 3.00 & 1.00 & 4.00 & 2.19 & 0.70 & 2.00 \\
\hline $\begin{array}{l}\text { Respondent's insurance } \\
\text { medical }\end{array}$ & 70.00 & 5.00 & 1.00 & 6.00 & 1.69 & 1.25 & 1.00 \\
\hline $\begin{array}{l}\text { Respondent's partner / } \\
\text { spouse's education }\end{array}$ & 72.00 & 6.00 & 1.00 & 7.00 & 4.56 & 1.14 & 4.56 \\
\hline $\begin{array}{l}\text { Respondent's partner / } \\
\text { spouse's age }\end{array}$ & 72.00 & 31.00 & 23.00 & 54.00 & 37.40 & 7.11 & 37.50 \\
\hline $\begin{array}{l}\text { Respondent's monthly } \\
\text { income after tax } \\
\text { (Lithuanian currency) }\end{array}$ & 65.00 & 6000.00 & 0.00 & 6000.00 & 1963.51 & 1056.53 & 1800.00 \\
\hline $\begin{array}{l}\text { Respondent's weekly } \\
\text { time with kids (total) }\end{array}$ & 64.00 & 145.00 & 1.00 & 146.00 & 25.74 & 26.78 & 20.00 \\
\hline
\end{tabular}

Note. Based on 73 respondents completing questionnaires

\section{Models}

Model 1 selected weekly paternal time allocation with children as the dependent variable, aggregating time across parental assistance with school work; shared chores; direct interaction; entertainment time together (watching television, opera, theater, or movies); and walking and sports. Independent variables included family monthly income in Lithuanian Litas1000 L is about \$370); monthly paternal consumption of alcohol; paternal self-reported health and availability of the medical insurance.

Model 2 constructed spousal time allocation for children as dependent variable as an aggregate sum of weekly hours with children with the same elements as in the paternal case. For independent variables in Model 2 I included spousal education and age; paternal weekly time with children as defined earlier and monthly income after taxes.

Model 3 is the complement of Model 2 again with paternal time with as the dependent variable and paternal education and age; maternal weekly time with children; and the same monthly household income after taxes as repressors. 
Results

The F score for Model 1 is highly significant $(p \leq .01)$ suggesting scientific legitimacy of the empirical results of this study to contribute towards existed body of scientific literature and the data variation explained through the model using the more conservative adjusted R-square is .15 . Adjusted R-square compensates for the number of independent variables in the model (unadjusted R-square .21).

The F score for Model 2 is very highly significant $(p \leq .001)$ even more so than previous model necessarily improving precision estimates of the findings in this paper. The variation of data explained by this is quite high, adjusted R-square .50 (unadjusted R-square .54).

Finally, the F score for Model 3, the complement of Model 2, is also very highly significant $(p<.001)$ with similar precision estimates of the findings. The data variation explained by this model using the adjusted R-square is .41 (unadjusted .64). The greater difference between unadjusted and adjusted numbers for Model 3 is due to fewer observations in Model 3 (less complete reporting of spousal variables), thus improving scientific estimates.

Model 1 examines paternal time with children relative to health-related indicators - health status, alcohol use, and medical insurance status plus after tax income (proxy for access to other resources). There was a slight income effect for after tax family income whereas in a separate model (not shown) total pre-tax family income was not significant indicating a differential tax rate effect which is new findings contributing towards improved scientific body of literature. With the modest adjusted R-squared explanatory power (.15), all significant negative predictors were health related - greatest paternal consumption of alcohol a dosed measure followed by negative health condition. Medical insurance was not significant (only 5 respondents were not covered - possibly short-term residents as Lithuania provides state insurance for citizens and long-term residents in addition to private options).

Models 2 and 3 provide a comparison of respondent and spousal time with children focusing on common after tax income, respective age and education, checking for substitutionary or complementary effects with the other's time allocation with children.

In Model 2, spousal time variation accounted for is moderately high (.50 adjusted R-squared). Each additional spousal year of age predicting about 1.7 fewer weekly hours with children and was highly significant - consistent also with onaverage older children having increasing independence which could be identified as important consideration for public policy developments based on new scientific findings of this paper. Spousal educational level exhibited the largest significant positive coefficient $(5.493, p \leq .10)$, although the standardized beta places its relative impact at about half that of age per standard deviation difference. Paternal 
time allocation was complementary not substitutionary to spousal time allocation for children, but at less than unit parity $(.638, p \leq .001)$ : an additional paternal hour predicted about 38 minutes' additional spousal time investment which may play an important role in consideration of public policy developments including maternal and paternal leaves. Monthly after-tax income was not significant.

Model 3 compares the corresponding variables for paternal time allocation. Here paternal age and education, in contrast to the spousal model, were not significant. This is an interesting finding improving current state of existed body of literature related to the different returns from (paternal vs maternal) education with notable spillover effects upon the children, thus introducing additional scientific evidence in support of public policy development. However spousal time allocation was similarly complementary to paternal time allocation $(0.358, p \leq .001)$ an additional hour of maternal time investment carried forward the paternal time investment by only about 22 minutes - about $40 \%$ less than did the paternal hour for spousal child-time investment.

\section{Discussion}

Since emerging from the Soviet ambit in 1991, the Republic of Lithuania (population of about 3.5 million) comprises the largest economy of the Baltic States since transition to multiparty democracy (per capita income ca. \$18,700). Although the first Baltic republic to break from Soviet hegemony, in economic freedom it lags behind neighboring Estonia (Heritage Foundation, 2016). National tax revenue (including VAT) absorbs $32.6 \%$ of GDP (2011), double the $15 \%$ of U.S. GDP, and a significant under-the-table economy has developed. Lithuania ranked 38th in least corruption in 2016 (59 with 100 being "very clean") (Transparency International, 2016). The Human Development Index - a composite measure based on life expectancy, education and income (United Nations Development Programme [UNDP], 2014) - ranks Lithuania 37th of 188 countries (at the lower margin of "very high" development). Health expenditures account 6.6\% of GDP (2014). Life expectancy by sex differs by 10 years (circa 80 for females and 70 for males) (Central Intelligence Agency, 2016).

As noted earlier, Model 1 examining paternal time with children includes health-related indicators and family income as a broad proxy for access to resources. The most potent negative predictors of time spent with children, in order, were alcohol consumption and health status, with alcohol consumption having the greatest comparative magnitude of effect per standard deviation of difference according to standardized betas. There is a broad literature on the impact of alcohol on health and on relationships, although in some cases increased alcohol consumption may 
be subsequent to poorer health and related limitations ('self-medication'). Higher consumption in the sample powerfully predicts decreased time with children which is one of the most valuable contribution to improve scientific findings within the existed literature. However self-reported health status, controlling for alcohol consumption, is independently almost as powerful a predictor of time spent. (The ovelap between the two contributes to a lower R-squared, part of which is mediated by the impact of alcohol on health.) Thus, parental self reported health is clearly impacting directly and indirectly the welfare of the children further supporting the importance of improved public policy developments. While insurance status did not reach significance (given broad coverage in Lithuania regardless of employment status), impact of after-tax income is modest in size and significance (.004, $p \leq .10)$ and as predictor of paternal weekly time allocation with children. Interestingly, it is not just the access to the resources by parents determining the impact upon the welfare of the children but rather the outcome of self reported health status determined by resource availability to play a significant contribution towards the children welfare. In other words, based upon the findings of this paper it is not merely sufficient for public policies to make resources available for parents but rather such resources must have productive outcome including considerable improvement of parental health status. In the previous United States study utilizing a richer model (Medvedovski \& Allison, 2012) income or poverty level multiplier were not associated with paternal time allocation with children. Were Lithuania's shadow economy fully taxed, the gradient might increase. Lithuania's $15 \%$ flat income tax lends higher marginal utility to every additional Euro in higher incomes compared to a progressive tax structure. The shadow economy, characterized by some as 'low tax-morale' (Swedbank, 2010), has been estimated to comprise upwards of one-third of Lithuanian GDP.

In Models 2 and 3 examining age, education, income and cross time investment effects on time allocation with children, there is striking complementarity in paternal and spousal time investments with children serving as novel contribution to the existed science and difference in the impact of age and education (significant for spouse but not paternally). Consistent with previous discussion the spousal education significantly translates positively into time with children (the sign on paternal education was negative but did not reach significance). The marginal paternal hour was accompanied by a spousal complement almost twice the magnitude of the paternal complement for a marginal spousal hour with children. It is notable that in Lithuania maternal paid leave after the birth of a child can last up to three years. This is the time period where public policies may benefit from considering the findings of this paper including resource distribution to specifically target parental improvement of self reported health status. Additionally, institutional 
childcare is heavily subsidized regardless of income so that the internal household economic trade-off between the marginal working hour vs. hourly cost of childcare vs. hourly opportunity cost of time with particularly young children is not as great in Lithuania as in the U.S. These factors work toward a complementary effect and away from a substitutionary effect in paternal and spousal time investments with children whereas in the U.S., given higher opportunity costs, there would be greater pressure toward substitution. These findings serve in support of existed scientific literature where cultural relevancy is paramount to determine more successful public policies. In addition, there is a positive government child-subsidy to family income per child born providing a comparatively higher marginal economic utility to having more children. Lithuania's total fertility rate (TFR), however, is estimated at 1.59 in 2016, ranked 185th of 222 countries, compared to a TFR of 1.87 , ranked 142nd, for the U.S. (CIA, 2016). In this regard population politics plays a role in increased complementarity over all, while a greater majority of family income is still generated paternally in Lithuania. This may also explain in part the higher complementary impact on spousal time investment with children of a paternal hour than the marginal spousal hour on paternal time with children. With these variables, however, after tax income did not reach significance for the time allocation for either spouse.

\section{Conclusions}

To our knowledge this is the first study to examine time allocation for children in Lithuania focusing on the dimension of health, alcohol consumption, and the trade-off of paternal and spousal time investment with children. Many studies in the reviewed literature examine parental time allocation for children in the U.S. (Medvedovski \& Allison, 2012). An assumption that time allocation patterns and cross effects would be similar in a Lithuanian cultural context compared to the U.S. is not justified in advance as the findings of this paper further demonstrate contributing towards improvement of the existed public policies in Lithuania, in particular given differences in state public policy toward general child-related subsidies and generous leave policies including sick leave policies, temporal and monetary, responsive to Lithuania's current population profile and population pyramid trend. This exploration invites further expanded research in this direction identified by this research paper to significantly improve scientific support of the existed public polices in Lithuania. A constraint for analysis of this data is the relatively modest sample size unlikely impacting the direction to further expanding research. Additionally, direct comparison between paternal and maternal allocation is not likely possible in this data for some dimensions. Since this research paper is braking a 
new ground in science further research is needed to confirm whether indications from the sample in the area of Klaipeda, Lithuania, are generalizable to Lithuania as a whole. This will be helpful as well for comparison with Estonia and Latvia in their ongoing economic and social transition to advance healthy public policies based upon improve scintifica findings as this paper suggests.

\section{References}

Central Intelligence Agency (CIA). (2017). Country comparison. Total fertility rate. World Factbook. Retrieved from https://www.cia.gov/library/publications/the-world-factbook/rankorder/2127rank.html

Craig, L. (2006). Parental Education, Time In Paid Work and Time With Children: an Australian Time-Diary Analysis". The British Journal of Sociology, Vol. 57, p. 553-575.

European Community Household Panel (ECHP). (2012). Formal childcare by duration and age group. Less than 3 years and between 3 years and compulsory school age (2006-2010). Retrieved from http://epp. eurostat.ec.europa.eu/portal/page/portal/eurostat/home/, specifically: http://appsso.eurostat.ec.europa.eu/ nui/setupModifyTableLayout.do

15min.lt. (2012, May 12). Lithuanians marry increasingly late. Retrieved from www.15min.lt/en/article/culturesociety/lithuanians-marry-increasingly-late-528-218184

Fleurbaey, M. (2009). Beyond GDP: The quest for a measure of social welfare. Journal of Economic Literature, Vol. 47(4), p. 1029-1075.

Garcia-Mainar, I., Molina, J., Montuenga, V. M. (2011). Gender differences in childcare: Time allocation in five European countries. Feminist Economics, Vol. 17(1), p. 119-150.

Guryan, J., Hurst, E., Kearney, M. (2008). Parental education and parental time with children. Journal of Economic Perspectives, Vol. 22(3), p. 23-46.

Connelly, R., Kimmel, J. (2009). Spousal Influences on Parents' Non-Market Time Choices. Review of Economics of the Household, Vol. 7, p. 361.

Harvie, D., Slater, G., Philp, B., Wheatley, D. (2009). Economic well-being and British regions: The problem with GDP per capita. Review of Social Economy, Vol. 67(4), p. 483-505.

Heritage Foundation. (2016). Lithuania. Index of Economic Freedom. Retrieved from http://www.heritage.org/ index/country/lithuania

Kanopiene, V. (2011). Women's employment in Lithuania: Trends, structure, opportunities. (European Science Foundation. TransEurope Social Sciences Research Network. Working Paper No. 35). Retrieved from http:/www.transeurope-project.org/UserFiles/File/Papers/TransEurope_WP_35_Kanopiene_Final.pdf

Medvedovski, D. M., Allison, K. C. (2012). Determinants of father-child time and family labor allocation. Academy of Business Research Journal, Vol. 2, p. 31-51.

Milkie M. A., Mattingly, M. J., Nomaguchi, K. M., Bianchi, S. M., Robinson, J. P. (2004). The Time Squeeze: Parental Statuses and Feelings about Time With Children. Journal of Marriage and Family, Vol. 66, p. 739-761.

National Center for Fathering. (1999). Personal Fathering Profile training manual. Shawnee Mission, KS: The National Center for Fathering.

Nock, S. L., Kingston, P. W. (1988). Time with Children: The Impact of Couples' Work-Time Commitments. Social Forces, Vol. 67, p. 59-85.

Statistics Lithuania. (2012). Lithuania in figures 2012. Retrieved from http://www.stat.gov.lt/en/catalog/list/?cat $\mathrm{y}=1$

Swedbank. (2010, December 27). Lithuania's shadow economy and what's behind it. Retrieved from http:// newsroom.swedbank.com/en/Publications/2010/Lithuanias-shadow-economy-and-whats-behind-it/

Transparency International. (2016). Corruption by country / territory. Retrieved from http://www.transparency. org/country\#LTU

United Nations Development Programme (UNDP). (2014). Inequality-adjusted Human Development Index (IHDI). Human Development Reports (HDR). Retrieved from http://hdr.undp.org/en/statistics/ihdi/

Zaborskis, A., Zemmaitiene, N., Borup, I., Kuntsche, E., Moreno, C. (2007). Family joint activities in a crossnational perspective. BMC Public Health, Vol. 7, p. 94. 